32(2) STUDY ON THE AMERICAN CONSTITUTION (forth. circa Sept. 2021)(peer reviewed) (South Korea)

\title{
Understanding Nativist Elements \\ Relating to Immigration Policies and to the American Constitution's Natural Born Citizen Clause
}

\section{Seth Barrett Tillman*}

\section{Introduction.}

I start with a definition. A "nativist" element of a legal system is one which preserves some benefit for, all or some of, the nation's citizens or its indigenous inhabitants, as opposed to granting that benefit neutrally to citizens and immigrants alike.

Not so long ago the essential morality of such a distinction was considered so obvious that no defense was thought to be necessary. ${ }^{1}$ Indeed, in many traditional societies there is no distinction between the indigenous inhabitants (that is, the people) and the nation. Any attempt by

\footnotetext{
* Lecturer, and Associate Professor (as of 1 October 2021), Maynooth University Department of Law. Roinn Dlí Ollscoil Mhá Nuad. I thank Dean Eric Enlow (원장님), Handong International Law School, Korea, and the late George W. Carey $\&$ James McClellan for their words of encouragement.

${ }^{1}$ See Cabell v. Chavez-Salido, 454 U.S. 432, 439-40 (Supreme Court of the United States 1981) (White, J.) ("The exclusion of aliens from basic governmental processes is not a deficiency in the democratic system but a necessary consequence of the community's process of political self-definition. Selfgovernment, whether direct or through representatives, begins by defining the scope of the community of the governed and thus of the governors as well: Aliens are by definition those outside of this community. Judicial incursions in this area may interfere with those aspects of democratic self-government that are most essential to it." (emphasis added)); Sugarman v.Dougall, 413 U.S. 634, 647 (Supreme Court of the United States 1973) (Blackmun, J.) (explaining that the power to make citizenship a qualification for public office "inheres in the State by virtue of its obligation...to preserve the basic conception of a political community" (quotation marks omitted) (emphasis added)); WILLIAM RAWLE, A VIEW OF THE CONSTITUTION OF THE UNited StATES OF AMERICA 80-81 (Philadelphia, Pennsylvania: H.C. Carey \& I. Lea, 1825) (offering no defense of the Natural Born Citizen Clause), $<$ https://tinyurl.com/2bn58ukj>.
} 


\section{DRAFT: Not for distribution DRAFT: Not for quoting}

\section{2(2) STUDY ON THE AMERICAN CONSTITUTION (forth. circa Sept. 2021)(peer reviewed) (South Korea)}

a government to treat newcomers equally in all respects would have been akin to incomprehensible. ${ }^{2}$

Today, in the West, there is a growing view that all such distinctions are actual or tantamount to invidious racial or ethnic discrimination. Still such distinctions have long-standing bona fides-even in Western societies. For example, under the United States Constitution (1787), all elected federal positions in the national government must be held by citizens. ${ }^{3}$ Members of the diet's lower chamber must be 25 years old, be an inhabitant of the state in which they are elected, and have held citizenship for at least 7 years. ${ }^{4}$ Similarly, members of the upper chamber must be 30 years old, be an inhabitant of the state in which they are elected, and have held citizenship for at least 9 years. ${ }^{5}$ Like holding a congressional seat, eligibility to hold the presidency and vice presidency requires that the candidate meets an age requirement (at least 35 years old) and a residency requirement (at least 14 years in the United States). ${ }^{6}$ However, unlike

\footnotetext{
${ }^{2}$ See, e.g., Ambach v. Norwick, 441 U.S. 68, 75 (Supreme Court of the United States 1979) (Powell, J.) ("The distinction between citizens and aliens, though ordinarily irrelevant to private activity, is fundamental to the definition and government of a State. The Constitution itself refers to the distinction no less than 11 times ...." (emphasis added)); Foley v. Connelie, 435 U.S. 291, 296 (Supreme Court of the United States 1978) (Burger, C.J.) ("[I]t is clear that a State may deny aliens the right to vote, or to run for elective office, for these lie at the heart of our political institutions." (emphasis added)).

3 The United States Constitution imposes qualifications on federal electorsalbeit none relate to citizenship. See United States Constitution, Article 2, Section 1, Clause 2 (the Elector Incompatibility Clause).

${ }^{4}$ See United States Constitution, Article 1, Section 2, Clause 2.

${ }^{5}$ See ibid., Section 3, Clause 3, amended by Amendment 17. Under Article 1, senators were originally elected by the United States' constituent state legislatures. Under Amendment17, senators are now popularly elected. However, if a senate seat is vacant, a temporary senator may be chosen by a state governor to fill the senate vacancy. Ibid. In such circumstances, it is not clear that the senator must be an inhabitant of that state.

${ }^{6}$ See ibid., Article 2, Section 1, Clause 5, amended by Amendment 12. This clause, the Natural Born Citizen Clause, is also sometimes called the Presidential Qualifications Clause or Presidential Eligibility Clause. The prevailing view is that the age, inhabitancy, and citizenship requirements applicable to the
} 


\section{DRAFT: Not for distribution DRAFT: Not for quoting}

\section{2(2) STUDY ON THE AMERICAN CONSTITUTION (forth. circa Sept. 2021)(peer reviewed) (South Korea)}

holding a congressional seat, eligibility to hold the presidency and vice presidency is limited to natives, ${ }^{7}$ or more properly, using the language of the United States Constitution, to "natural born citizen[s]" - a person who is born in the United States and a citizen since birth. ${ }^{8}$

presidency also apply to the vice presidency. See ibid., Amendment 12, Clause 4 (" $[\mathrm{N}]$ o person constitutionally ineligible to the office of President shall be eligible to that of Vice-President of the United States."). See generally Bruce G.Peabody and Scott E. Gant, The Twice and Future President: Constitutional Interstices and the Twenty-Second Amendment (1999) 83 MinnesotA LAW REVIEW 565; Bruce G. Peabody, The Twice and Future President Revisited: of Three-Term Presidents and Constitutional End Runs (2016) 101 Minnesota LAW REVIEW HEADNOTES 121. Congressional seats have an "inhabitan[cy]" requirement, but the presidency has a "residen[cy]" requirement. It is not entirely clear if or how these terms were intended to be distinguished. Compare Franklinv. Massachusetts, 505 U.S.788, 804 (Supreme Court of the United States 1992) (O'Connor, J.) (noting that the first census enumeration act, Act of 1 March 1790, \$5, 1 Stat. 103, used "usual place of abode," "inhabitant," "usual reside[nt]" synonymously), with Schaefer v. Townsend, 215 F.3d 1031, 1036 n.5 (United States Court of Appeals for the Ninth Circuit 2000) (O'Scannlain, J.) (suggesting that "inhabitant" was a "deliberate" selection, and citing James Madison for the proposition that "both [terms] were vague, but [inhabitant] would not exclude persons absent occasionally for a considerable time on public or private business"). It appears the Massachusetts Constitution (1780) used "inhabitant" and "residence" indistinguishably. Compare Massachusetts Constitution, Part II, Chapter 2, Section 1, Article 2 (1780) " The governor shall be chosen annually; and no person shall be eligible to this office, unless, at the time of his election, he shall have been an inhabitant of this commonwealth for seven years next preceding; and unless he shall, at the same time, be seized, in his own right, of a freehold, within the commonwealth, of the value of one thousand pounds; and unless he shall declare himself to be of the Christian religion."), with ibid., Section 2, Article 1 ("There shall be annually elected a lieutenant-governor of the commonwealth of Massachusetts . . . who shall be qualified, in point of religion, property, and residence in the commonwealth, in the same manner with the governor ....").

${ }^{7}$ See, e.g., Schneider v. Rusk, 377 U.S. 163 (Supreme Court of the United States 1964) (Douglas, J.) (using "native," "native born," "native citizen," and "natural born citizen" interchangeably).

8 See United States Constitution, Article 2, Section 1, Clause 5, amended by Amendment 12; see also ibid., Amendment 14 (defining citizenship by place of birth). Undoubtedly, there is some long-standing debate regarding the precise contours or boundaries of "natural born citizen" as used in the United States Constitution. The courts of the United States have not definitively determined the scope of Article 2's language, and it is not the purpose of this Article to resolve this issue. See, e.g., Paul Clement and Neal Katyal, On the Meaning of Natural Born Citizen (2005) 128 HARVARD LAW REVIEWFORUM 161, 161 (“[T]he relevant materials 


\section{DRAFT: Not for distribution DRAFT: Not for quoting}

\section{2(2) STUDY ON THE AMERICAN CONSTITUTION (forth. circa Sept. 2021)(peer reviewed) (South Korea)}

This essay asks two related questions: Is a society justified in distinguishing citizens and immigrants? Is a society justified in distinguishing citizens from birth from those who become citizens subsequently through naturalization?

\section{A. Crossing an International Frontier.}

One basic difference between citizens and non-citizens relates to the law of return to one's home. ${ }^{9}$ That is, the right to enter the country from the outside-albeit, while holding now standard identification papers, such as a passport. ${ }^{10}$ A citizen's right of return to his home might be an absolute right, vested by the nation's constitutional text, or an implied right recognized by the nation's courts. Alternatively, the right may be defeasible, but the citizen's substantive position is preserved by a

clearly indicate that a 'natural born Citizen' means a citizen from birth with no need to go through naturalization proceedings."); Mary Brigid McManamon, The Natural Born Citizen Clause as Originally Understood (2015) 64 CATHOLIC UNIVERSITY LAW REVIEW 317, 347 (concluding that any person who is born in the United States is a natural born citizen, excepting children of enemy soldiers and foreign ambassadors, and that no one born outside the United States to U.S. citizen parents is a natural born citizen eligible to be President "aside from children born to U.S. ambassadors or [U.S.] soldiers" while they are posted abroad); Jill A. Pryor, The Natural-Born Citizen Clause and the Presidential Eligibility: An Approach for Resolving Two Hundred Years of Uncertainty (1988) 97 YALE LAW JOURNAL 881, 88182 ("Despite its apparent simplicity, the natural-born citizen clause of the Constitution has never been completely understood.").

${ }^{9}$ See, e.g., Book of Statutes (Israel 1950), No. 51, p. 159, as amended in 1954 and 1970, $<$ https://tinyurl.com/a654f4e8>. See generally Nir Kedar, Ben-Gurion's view of the place of Judaism in Israel (2013) 32(2) JOURNAL OF IsRAELI HisTORY: POLITICS, SOCIETY, CULTURE 157. Undoubtedly, the concept of "home" is contestable, particularly in a world of changing identities and borders. But see Elizabeth Hicks, Governing During Crises Policy Brief No.11, A Right to Come Home? Repatriation Rights \& Policy in Australia (Melbourne School of Government, 15 April 2021), 2 ("In the absence of an express bill of rights, Australia largely relies on political mechanisms to hold the government to account, including with regard to the proportionality of COVID-19 related international border restrictions. Political mechanisms have failed to prioritise the right of citizens to return ahead of other political and economic concerns relevant to government business.").

${ }^{10}$ See, e.g., 8 United States Code $\$ 1185$ (b) (mandating passport requirement). 


\section{DRAFT: Not for distribution DRAFT: Not for quoting}

\section{2(2) STUDY ON THE AMERICAN CONSTITUTION (forth. circa Sept. 2021)(peer reviewed) (South Korea)}

procedural right to access meaningful judicial review administered by independent courts. ${ }^{11}$

As a general matter, modern constitutions do not vest non-citizens with any such coordinate right to cross the frontier and enter the country. ${ }^{12}$ Indeed, keeping non-citizens out, absent permission to enter from the regularly constituted administrative or frontier authorities, has traditionally been thought to be one of the state's most basic obligations to its citizens. ${ }^{13}$ Non-citizens have no absolute or constitutional right to enter. ${ }^{14}$ And, as a general matter, non-citizens have no clear right to judicial

${ }^{11}$ Cf. Trump v. Hawaii, 138 S. Ct. 2392, 2419 (Supreme Court of the United States 2018) (Roberts, C.J.) (“[A]lthough foreign nationals seeking admission have no constitutional right to entry, this Court has engaged in a circumscribed judicial inquiry when the denial of a visa allegedly burdens the constitutional rights of a U.S. citizen."); Steve Vladeck, Unpacking (Some of) the Legal Issues Surrounding Hoda Muthana, Just SECURITY (Feb. 20, 2019), <https://tinyurl.com/5yene456> ("Although the Supreme Court [of the United States] has never squarely been presented with such a case, it seems likely that, in an appropriate case, the Court would recognize that someone who is lawfully a citizen has the right to return to the United States.").

12 See, e.g., Department of Homeland Security v. Thuraissigiam, 140 S. Ct. 1959 (Supreme Court of the United States 2020) (Alito, J.) (holdingthat an alien crossing frontier has no constitutional right to habeas corpus); Knauff v. Shaughnessy, 338 U.S. 537 (Supreme Court of the United States 1950) (Minton, J.) (holding that an alien seeking entry into the United States has noright to any proceduresother than those prescribed by Congress).

${ }^{13}$ For example, isolation, seclusion, and limiting foreign contacts were state policy during Japan's Tokugawa shogunate for over 200 years. See Edict of 1635 (Tokugawa Bakufu), <https://tinyurl.com/cjw6mz46>. Describing this period, as is commonly done, as one of isolation, etc is merely one possible characterization. Another possible, more generous, and less common characterization (except, perhaps, in Korea) is that Japan was at peace with its neighbours and the world.

${ }_{14}$ Many nations have adopted international treaties and conventions giving foreigners a limited entry right (sometimes supported with administrative or judicial review) based on asylum or refugee status, escaping war zones and torture, etc. These international commitments become judicially enforceable after they are incorporated into domestic law. See, e.g., Immigration and Nationality Act, 8 United States Code $\$ 1158$ (a) (authorizing asylum to refugees who can establish "persecution" in home country); Convention Against Torture, 8 United States Code of Federal Regulations \$208.16(c)(2) (granting an applicant relief if that person can show that it is "more likely than not that he or she would be tortured if” relief were denied). The European Union has a free travel right 


\section{DRAFT: Not for distribution DRAFT: Not for quoting}

\section{2(2) STUDY ON THE AMERICAN CONSTITUTION (forth. circa Sept. 2021)(peer reviewed) (South Korea)}

review relating to their being excluded from entry. Where judicial review is provided, it is not a constitutional right, but a statutory right or a right arising in connection with the mundane judicial review which springs automatically from authorized administrative proceedings.

The long-standing and consistent historical practice of Western countries - i.e., treating their own citizens differently from foreigners - is a starting point for determining the propriety of a disputed practice. ${ }^{15}$ Admittedly, such a historical fact is only a starting point; it does not fully determine our answer. Many long-established practices are now rejected as anti-modern, if not disgraceful. Slavery and serfdom come to mind. But slavery and serfdom were part of the pre-modern and pre-democratic West. $^{16}$ The fact that modern Western democratic nations have consistently maintained, ratified, and recently enacted many such distinctions, i.e., distinguishing their own citizens and foreigners, gives this widespread practice democratic bona fides. That is some justification for the continuation of the practice of distinguishing citizens and foreigners at international frontiers.

The counter-view might be that when citizens and their representatives govern their nations in ways which favour "their own" that amounts to something akin to regulatory capture.${ }^{17}$ Here, the insiders' (i.e., citizens') excluding outsiders (i.e., non-citizens) from being physically present in the state by failing to consider the latter's interests (i.e., interests

across member states' borders - but the right extends to member states' citizens, and it does not expressly extend to non-citizens. See Citizens' Rights Directive 2004/38/EC, <https://tinyurl.com/4uj3cskr >.

${ }^{15}$ The Federalist No. 69, at n. *(1788) (Alexander Hamilton) ("[I]tis always justifiable to reason from the practice of a government, till its propriety has been constitutionally questioned.").

${ }^{16}$ See, e.g., United States Constitution, Amendment13 (1865) (banning slavery).

${ }^{17}$ See David Freeman Engstrom, Corralling Capture (2013) 36 HARVARD JOURNAL OF LAW AND PUBLIC POLICY 31, 31 ("Put another way, arguments about capture necessarily turn on a difficult counterfactual inquiry about what publicinterested regulation would look like in capture's absence.”). 


\section{DRAFT: Not for distribution DRAFT: Not for quoting}

\section{2(2) STUDY ON THE AMERICAN CONSTITUTION (forth. circa Sept. 2021)(peer reviewed) (South Korea)}

which the state ought to value) would be characterized as wrongful. This process is particularly unfair because non-citizens already lack the normal legal protections available to others (i.e., the state's citizens). To put it another way, a government run by statesmen (or Platonic guardians, depending on one's point of view) should value the interests of noncitizens, in much the same way it is expected to value the interests of all its citizens (even those who cannot vote because they are underage or labour under some disability or incapacity). The normative force of this point of view might be grounded in a world-wide utilitarian framework, as opposed to a local just-society framework. ${ }^{18} \mathrm{Or}$, it might be grounded in the view that the accident of the place of one's birth ${ }^{19}$ or the accident of one's parentage ${ }^{20}$ should not determine one's most significant life chances. Because all such immutable characteristics are beyond the control of the applicant seeking entry across an international frontier, one might argue that granting or denying entry on such grounds is unjust. This Author is aware of no court of

${ }^{18}$ See generally JoHn RAWLs, A THEORY OF Justice (Cambridge, Massachusetts: Belknap Press, 1971) (arguing that a fair evaluation of the distribution of primary goods is to be reckoned at the level of the nation state).

${ }^{19}$ See, e.g., Randall Kennedy, A Natural Aristocracy? (1995) 12 ConstituTIONAL COMMENTARY 175, 176 ("This idolatry of mere place of birth [in the Natural Born Citizen Clause] seems ... an instance of rank superstition."); Robert Post, What is the Constitution's Worst Provision?(1995) 12 CONSTITUTIONAL COMMENTARY 191, 192 ("Our constitutional order does not ordinarily distribute the prerogatives of citizenship on the basis of where or how one is born."). Isn't Professor Post's position undertheorized? United States citizenship itself (even if not its individual prerogatives) flows from the accident of place of birth. See United States Constitution, Amendment 14, Section 1 (1868). Furthermore, naturalized citizens can be stripped of their U.S. citizenship for fraud in connection with naturalization proceedings, but U.S. citizens by birth cannot stripped of their citizenship in this manner. Moreover, some "prerogatives of citizenship" do flow from one's place of birth. An in-state college tuition benefit is one such example.

${ }^{20}$ During the American Civil War, both sides facilitated foreigners' participating in their armies, even as senior officers. On the Union side, entire organized regiments-officers and soldiers-were composed of foreigners-e.g., Irish, German, etc. See William L. Burton, Melting Pot Soldiers: The Union's Ethnic REgiments (Ames, Iowa: Iowa State University Press, 1988), $<$ https://tinyurl.com/m3j52e6v $>$. 


\section{DRAFT: Not for distribution DRAFT: Not for quoting}

\section{2(2) STUDY ON THE AMERICAN CONSTITUTION (forth. circa Sept. 2021)(peer reviewed) (South Korea)}

record which has sought to justify an applicant's entry across an international frontier on such grounds.

The question of whose welfare a nation's government ought to value, prize, or maximize is not entirely dissimilar to the commensurate question in company law. The members of a board of directors of a corporation are elected by its stockholders, ${ }^{21}$ and they are responsible to its stockholders. ${ }^{22}$ As a general matter, the board is charged with maximizing the stockholders' returns. ${ }^{23}$ But is that the board's entire duty? What thirdparty interests (if any) should the board consider when making decisions? ${ }^{24}$ Of course, in maximizing the stockholders' returns, a board will frequently consider third-party interests which it believes are aligned with its stockholders' interests. For example, a board might believe (and rightly so) that granting a benefit, even at some significant cost, to its workers, or to inhabitants where its manufacturing facilities are located, or, perhaps, establishing a reputation for protecting the environment will, ultimately, resound to the stockholders' long-term financial interests. The more difficult question is: When the board (if ever) should make a concrete

\footnotetext{
${ }^{21}$ See 8 Delaware General Corporation Law §141(b) (providing for the election of directors by stockholders).

${ }^{22}$ See ibid., \$141(k) (providing for the removal of directors by stockholders).

${ }^{23}$ See, e.g., Revlon, Inc. v. MacAndrews \& Forbes Holdings, Inc., 506 A.2d 173, 182 (Supreme Court of Delaware 1986) (Moore, J.) (explaining that when the board is auctioning the corporate entity, "[s]elective dealing to fend off a hostile but determined bidder was no longer a proper objective. Instead, obtaining the highest price for the benefit of the stockholders should have been the central theme guiding director action."); ibid. ("A board may have regard for various constituencies in discharging its responsibilities, provided there are rationally related benefits accruing to the stockholders."). This understanding is hardly unique to directors and company law, but extends more broadly to other fiduciaries, such as trustees. See, e.g., Cowan v Scargill [1985] Ch. 270, 287 (High Court of England, Chancery Division) (Megarry, Vice Chancellor) ("When the purpose of the trust is to provide financial benefits for the beneficiaries, as is usually the case, the best interests of the beneficiaries are normally their best financial interests.").

${ }^{24}$ See generally Rivka Weill, Declassifying the Classified (2006) 31 DELAWARE JOURNAL OF CORPORATE LAW 891, 924-29 (describing wealth maximizing norms).
} 


\section{DRAFT: Not for distribution DRAFT: Not for quoting}

\section{2(2) STUDY ON THE AMERICAN CONSTITUTION (forth. circa Sept. 2021)(peer reviewed) (South Korea)}

sacrifice (not otherwise required by established law) reducing stockholders' returns in order to benefit third-parties?

To put it another way, an argument based on regulatory capture or public choice theory posits that the moral relationship between insiders and outsiders is one based on substantive equality, but that the machinery of democratic representation fails to reflect that equality. ${ }^{25}$ Hence, the capture by the "insiders" (i.e., citizens through the representatives who they elect) against the "outsiders" (i.e., immigrant non-citizens lacking voting rights). But if that perspective is fundamentally flawed, if insiders and outsiders are substantively different, then a government's treating citizens and non-citizens alike amounts to regulatory capture by the "outsiders" against the "insiders." ${ }^{26}$ Furthermore, where it is permissible for elected representatives to serve interests other than their citizenconstituents, standards for democratic oversight through voting become muddied, if not deeply problematic. In circumstances where monitoring and supervision become pragmatically difficult, then representatives have greater opportunities to engage in self-dealing, including entrenching themselves in office. ${ }^{27}$

\footnotetext{
25 See Foley v. Connelie, 435 U.S. 291, 294 (Supreme Court of the United States 1978) (Burger, C.J.) ("[T]he Court has treated certain restrictions on aliens with heightened judicial solicitude, a treatment deemed necessary since aliens pending their eligibility for citizenship-have no direct voice in the political processes." (citation and quotation marks omitted)).

${ }^{26}$ See ibid., at 295 ("A new citizen has become a member of a Nation, part of a people distinct from others. The individual, at that point, belongs to the polity and is entitled to participate in the processes of democratic decisionmaking. Accordingly, we have recognized a State's historical power to exclude aliens from participation in its democratic political institutions ...." (citation and quotation marks omitted) (emphasis added)).

${ }^{27}$ See Weill, supra note 24, at 926 ("[A]ny other rule that would require directors to maximize other constituencies' wealth would leave directors practically with no supervision. A servant told to serve multiple masters is a servant free of supervision, since he or she may always invoke the conflicting interests against each other. In other words, any rule other than one requiring directors to maximize shareholders' wealth is infeasible [as a practical programme for judicial oversight over corporate governance]."(footnote omitted)).
} 


\section{DRAFT: Not for distribution DRAFT: Not for quoting}

\section{2(2) STUDY ON THE AMERICAN CONSTITUTION (forth. circa Sept. 2021)(peer reviewed) (South Korea)}

The language of regulatory capture only opens the discussion, but it does not answer what is essentially a moral or normative question: ${ }^{28}$ Ought governments treat citizens and non-citizens the same? And if they should be treated differently, on what occasions, and to what degree?

Undoubtedly, the normative force of the position that a state, in some circumstances, may (and, sometimes, should) treat its citizens and noncitizens differently should not obscure the normative force of the counterposition: in many situations, it is perfectly sound (good, right, just, etc) to treat citizens and non-citizens entirely the same. For example, the Framers of the United States Constitution (1787) could have co-opted state courts to rule on all legal issues arising in connection with the new national government. Instead, the United States Constitution provided for separate federal courts, and it also authorized those courts' having "diversity" jurisdiction over disputes between United States citizens and aliens. It was feared that state courts would be engines of unfairness, which by favouring local litigants (i.e., United States citizens) would lead to reduced investment from and trade with foreigners. More importantly, it was also feared that leaving foreigners' commercial interests in the hands of state courts would risk war with foreign nations, because the latter would seek to vindicate the just interests of their citizens' commercial interests in the United States. ${ }^{29}$

The same moral and policy issue is at the root of any transnational or international utilitarian perspective-any such perspective posits that governments do not exist to serve their particular people. ${ }^{30}$ On this view,

\footnotetext{
${ }^{28}$ See Engstrom, supra note 17.

${ }^{29}$ See United States Constitution, Article 3, Section 2; Federalist No. 80 (1788) (Alexander Hamilton); Kevin R. Johnson, Why Alienage Jurisdiction?: Historical Foundations and Modern Justifications for Federal Jurisdiction over Disputes Involving Noncitizens (1996) 21YALE JOURNAL OF INTERNATIONAL LAW 1, 6.

${ }^{30}$ Compare JEAN RASPAIL, LE CAMP DES SAINTS (Paris, France: Robert Laffont, 1973) (fiction), with Enoch Powell MP, Shadow Secretary of State for Defence, Address
} 


\section{DRAFT: Not for distribution \\ DRAFT: Not for quoting}

\section{2(2) STUDY ON THE AMERICAN CONSTITUTION (forth. circa Sept. 2021)(peer reviewed) (South Korea)}

governments should maximize the interests of all people: citizens and noncitizens alike. One wonders if the proponents of this latter view really would see this framework implemented worldwide. It is one thing to suggest that a relatively wealthy Western nation should set aside the interests of some of its people, some of the time, on behalf of relatively poorly placed or victimized third-world outsiders. That said, if this international utilitarian perspective were truly implemented across the board, then third-world countries should set aside their peoples' interests (at times) in order to benefit inhabitants of the first-world. Would anyone care to argue that the parliament of Bangladesh, in deciding to enact legislation, should, all other things being equal, actively weigh the interests of the working poor in Europe and North America against the interests of its own most opulent elite? Does anyone actually believe this?

\section{B. Explaining the Nativist Elements of the United States Constitution's "Natural Born Citizen" Requirement?}

The Federal Convention which drafted the United States Constitution was scheduled to meet on 14 May 1787 in Philadelphia, Pennsylvania. But it was unable to muster a quorum until 25 May 1787. The convention met in secret sessions. It would conclude its meetings on 17 September 1787, when its work product, the proposed constitution, would be sent to the Articles Congress which then forwarded it to the thirteen states for ratification. Ratification would take place over the course of 1787 through 1788 . The new Constitution and government would be put into effect in 1788 and 1789, when the first federal elections were held, Congress convened, counted the votes of the electors for President and Vice President, and gave official notice to George Washington and John Adams that they had been elected President and Vice President, respectively.

Article 2, Section 1, Clause 5, the Natural Born Citizen Clause, states:

to the West Midlands Area Conservative Political Centre (Birmingham, England: Midland Hotel, 20 April1968)(non-fiction). 


\section{DRAFT: Not for distribution DRAFT: Not for quoting}

\section{2(2) STUDY ON THE AMERICAN CONSTITUTION (forth. circa Sept. 2021)(peer reviewed) (South Korea)}

No person except a natural born Citizen, or a Citizen of the United States, at the time of the Adoption of this Constitution, shall be eligible to the Office of President; neither shall any Person be eligible to that Office who shall not have attained to the Age of thirty-five Years, and been fourteen Years a Resident within the United States.

Although many records from the Federal Convention and the ratification period are extant, there are few records explaining the origins, meaning, and purpose of the Natural Born Citizen Clause. As one commentator has explained: "The deliberations of the Constitutional Convention of 1787 furnish no clues to the underlying purpose." ${ }^{31}$ As to the origin of the clause and its intellectual progenitors (to the extent it had any), little is known. In particular, extant records provide little guidance why the Constitution (1787) distinguishes "natural born citizens," i.e., citizens from birth, from immigrants who subsequently become naturalized citizens.

1. Pre-Federal Convention American Legal Sources. ${ }^{32}$ The Articles of Confederation (1781), which was the governing constitution of the United States prior to the Constitution of $1787,{ }^{33}$ had no executive presidency. It did have a presiding officer - a president of the Articles Congress - who was chosen from among the delegates. ${ }^{34}$ Under the Articles, neither the president, nor the delegates from the thirteen states had any qualifications

\footnotetext{
${ }^{31}$ Charles Gordon, Who can be President of the United States (1968) 28 MARYLAND LAW REVIEW 1, 3; Post, supra note 19, at 192 (noting that the Natural Born Citizen Clause is "remarkably innocent of both legislative history and judicial gloss"). Compare Gordon, supra passim (discussing constitutional limitations), with Seth Barrett Tillman, Who Can Be President of the United States?: Candidate Hillary Clinton and the Problem of Statutory Oualifications (2016) 5 BRITISH JOURNAL OF AMERICAN LEGAL STUDIES 95 (discussing statutory limitations).

${ }^{32}$ Some, albeit not all, commentators have suggested that the Constitution's "natural born citizen" language has the same meaning as "natural born subject" in pre-1787 British statutes. This interpretive issue has never been conclusively settled by the federal courts.

${ }^{33}$ See generally Articles of Confederation (1781); Abraham Lincoln, First Inaugural Address (4 March 1861) ("The Union is much older than the Constitution. It was formed in fact, by the Articles of Association in 1774."), $<$ https://tinyurl.com/znt4m3x7>.

${ }^{34}$ Articles of Confederation (1781), Article IX, Section 5.
} 


\section{DRAFT: Not for distribution DRAFT: Not for quoting}

\section{2(2) STUDY ON THE AMERICAN CONSTITUTION (forth. circa Sept. 2021)(peer reviewed) (South Korea)}

relating to citizenship, inhabitancy, or residency. ${ }^{35}$ In short, the Articles did not furnish a model for the Natural Born Citizen Clause.

Some have suggested that the model for the executive presidency in the United States Constitution (1787) was the New York Constitution (1777) or the Massachusetts Constitution (1780). ${ }^{36}$ The executive governor of New York under its 1777 constitution had no qualifications relating to citizenship, inhabitancy, or residency. ${ }^{37}$ The executive governor of Massachusetts under its 1780 constitution had qualifications relating to inhabitancy, property, and religion, but no qualifications relating to citizenship or age (which are found in the Natural Born Citizen Clause). ${ }^{38}$ It would appear that neither the Articles of Confederation (1781) nor preratification (i.e., pre-1787) state constitutions furnished working models for the Constitution of 1787's Natural Born Citizen Clause.

2. The Federal Convention: 1787. The first report of the clause's “natural born citizen" language emerges from the 4 September 1787 report

\footnotetext{
${ }^{35}$ See ibid., Article V, Clause 2 ("No State shall be represented in Congress by less than two, nor more than seven members; and no person shall be capable of being a delegate for more than three years in any term of six years; nor shall any person, being a delegate, be capable of holding any office under the United States, for which he, or another for his benefit, receives any salary, fees or emolument of any kind.").

${ }^{36}$ See, e.g., Federalist No. 69(1788) (Alexander Hamilton) ("The qualified negative of the President differs widely from this absolute negative of the British sovereign; and tallies exactly with the revisionary authority of the council of revision of this State, of which the governor is a constituent part. In th is respect the power of the President would exceed that of the governor of New York, because the former would possess, singly, what the latter shares with the chancellor and judges; but it would be precisely the same with that of the governor of Massachusetts, whose constitution, as to this article, seems to have been the original from which the convention have copied." (emphases added)). See generally Gregory E. Maggs, $A$ Guide and Index for Finding Evidence of the OriginalMeaning of the U.S. Constitution in Early State Constitutions and Declarations of Rights (2020) 98 NORTH CAROLINA LAW REVIEW 779. Judge Maggs now sits on the United States Court of Appeals for the Armed Forces.

${ }^{37}$ See New York Constitution (1777); Gordon, supra note 31, at 3 n.8.

${ }^{38}$ See supra note 6 (collecting authority from the Massachusetts Constitution (1780)).
} 


\section{DRAFT: Not for distribution DRAFT: Not for quoting}

\section{2(2) STUDY ON THE AMERICAN CONSTITUTION (forth. circa Sept. 2021)(peer reviewed) (South Korea)}

of the Federal Convention's Committee of Eleven. ${ }^{39}$ This was less than two weeks before the Convention concluded its business. The Committee of Eleven's proposed Natural Born Citizen Clause was reported without explanation as to why or on what authority it had added the phrase "natural born citizen," and on 7 September 1787, its proposed language was approved by the Convention without reported debate. ${ }^{40}$ The Committee of Style was impanelled on 8 September 1787; it reported on 12 September 1787. It made only minor modifications to the clause's text, ${ }^{41}$ and its proposed language was adopted by the Convention on 15 September 1787 , without any vote..$^{42}$ This became the clause's final text.

Not only was there no recorded discussion from the Federal Convention relating to the clause's "natural born citizen" language, there was little discussion of qualifications generally. Apparently, the first such discussion of citizenship-related qualifications was in the Hamilton Plan, which he put forward on 18 June 1787. Hamilton's Article IX, Section 1 states: "No person shall be eligible to the office of President of the United States unless he be now a Citizen of one of the States, or hereafter be born a

\footnotetext{
39 The Committee of Eleven received its instructions from the Convention on 31 August 1787. It reported to the Convention on 4 September 1787. See 5 DEBATES ON THE ADOPTION OF THE FEDERAL CONSTITUTION 506, 507 (Jonathan Elliot, ed., Washington, District of Columbia: n.p., 2d ed. 1845) (reproducing 4 September 1787 report, with modifications to Article IX, Section 2-using "natural-born citizen”).

40 See 2 The Records of the Federal Convention of 1787, at 532 and 536 (Max Farrand, ed., New Haven, Connecticut: Yale University Press, 1911) (7 September 1787 entry in the Convention's Journal and in Madison's notes, recording approval of the Committee of Eleven's proposed Natural Born Citizen's clause absent debate and absent a recorded vote showing division of the state delegations).

41 See 1 The Debates in the Several States Conventions, on the Adoption of the

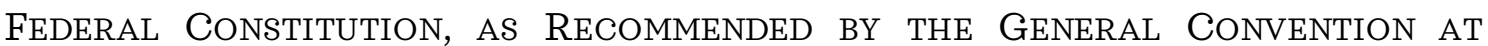
PHILADELPHIA, IN 1787, at 298, 302 (Jonathan Elliot, ed., Washington, District of Columbia: n.p., 2d ed. 1836) (reporting Committee of Style's draft and Natural Born Citizen Clause).

42 See ibid., at 311, 314 (reproducing the Convention's Journal for 15 September 1787).
} 


\section{DRAFT: Not for distribution DRAFT: Not for quoting}

\section{2(2) STUDY ON THE AMERICAN CONSTITUTION (forth. circa Sept. 2021)(peer reviewed) (South Korea)}

Citizen of the United States.” ${ }^{43}$ Although copies of his plan may have been circulated to the members, Hamilton's plan was not properly before the Convention: it was never formally voted on or adopted. ${ }^{44}$ It did not use anything like the phrase "natural born citizen."

The second such discussion is found in a 25 July 1787 letter from John Jay, writing from New York, to George Washington, in Philadelphia. At that time, Washington was President of the Convention. And, Jay was the United States Secretary of Foreign Affairs - a functionary of the Articles Congress. He was not a member of the Federal Convention, and there is no good reason to believe that he had any access to the Convention's ongoing secret deliberations and proposals. At this juncture, Jay was likely unaware that the Convention was to craft a single-person executive presidency. Jay wrote:

Permit me to hint, whether it would not be wise \& seasonable to provide a strong check to the admission of Foreigners into the Administration of our national Government, and to declare expressly that the Command[er] in Chief of the [A]merican army shall not be given to, nor devolve on, any but a natural born Citizen. ${ }^{45}$

More than a few have suggested that this letter was the source of the Constitution's “natural born citizen” language. More specifically, it has been suggested that this letter (or its contents) was informally circulated by Washington to other members of the Convention. But there is no actual evidence of Washington's having done so. Likewise, there is no record establishing that Jay's letter was the source of the Constitution's "natural

\footnotetext{
${ }^{43} 3$ RECORDSOF THE FEDERAL CONVENTIONOF 1787, at 617, 629 (Max Farrand ed., New Haven, Connecticut: Yale University Press, 1911).

${ }^{44}$ See ibid., at 617 (with Farrand noting that "this plan was not formally before the Convention"); 1 THE RECORDS OF THE FEDERAL CONVENTION OF 1787, at 300 (Max Farrand, ed., New Haven, Connecticut: Yale University Press, 1911) (reporting Robert Yates' notes from 18 June 1787, which stated that " $M r$. H. produced his plan"). Yates, like Alexander Hamilton, was a New York delegate to the Federal Convention.

${ }^{45}$ Letter from John Jay, Secretary of Foreign Affairs, to George Washington, President of the Constitutional Convention (25 July 1787), FOUNDERS ONLINE, $<$ https://tinyurl.com/35mukpcs $>$.
} 


\section{DRAFT: Not for distribution \\ DRAFT: Not for quoting}

\section{2(2) STUDY ON THE AMERICAN CONSTITUTION (forth. circa Sept. 2021)(peer reviewed) (South Korea)}

born citizen" language. More importantly, Jay's advice was not followed in any meaningful fashion.

Jay, as foreign minister, was likely familiar with then extant British practice. In 1787, when Jay wrote his letter to Washington, the British monarch and his family could be foreigners, but the English Parliament had imposed statutory qualifications, under the Act of Settlement (1701), on appointed officers. Under the text of the 1701 English statute, one could not hold an appointed position unless one had been born in the king's dominions ${ }^{46}$-even if one were subsequently naturalized. ${ }^{47}$ To the extent that Jay was addressing appointed "officers of or under the United States" as part of "the administration of [the] national Government," his advice was not followed. Under the Constitution of 1787, there are no constitutionally mandated qualifications, much less citizenship-related qualifications, for appointed positions in the federal government. In short, American practice, as mandated by the United States Constitution (1787), was the opposite of British practice, as mandated by British statutory requirements, at that time. The former had no formal qualifications relating to appointed federal positions; the latter required the appointee to be a subject of the king when born. This is some substantial indication that Jay's letter, even assuming it had been circulated to the members, was not followed in regard to the largest number of positions in what would become the United States government's administrative apparatus.

46 See Hilaire Barnett, Constitutional \& Administrative LaW 16 (London, England: Routledge Cavendish, 7th ed.2009) (explainingthat the Channel Islands and Isle of Man are not part of the United Kingdom, but "they are part of Her Majesty's dominions”). See generally Sodor and Man (Bishop) v Derby (Earl) (1751) 2 Vesey Senior Reports 337.

47 See AKHIL REED AMAR, AMERICA's CONSTItUtion: A BIOGRAPHY 164-65 (New York: Random House Trade Paperbacks, 2005) (describing the legal effect of the Act of Settlement). See generally Act of Settlement, 1701, 12 and 13 Will. 3, ch. 2, § 3, <https://www.legislation.gov.uk/aep/Will3/12-13/2>. 


\section{DRAFT: Not for distribution DRAFT: Not for quoting}

\section{2(2) STUDY ON THE AMERICAN CONSTITUTION (forth. circa Sept. 2021)(peer reviewed) (South Korea)}

In contrast to appointed federal officers, all elected federal officials do have constitutionally mandated citizenship qualifications. So in this sense, even if not in consequence of Jay's letter, one might argue that Jay's general approach was adopted by the Convention. However, this assumes that Congress was understood as part of the "administration of [the] national Government.” But that assumption may be wrong-the language of "administration" was frequently reserved for Executive Branch positions. Congress' role is better characterized as legislative (as in law-making), as opposed to administrative (as in law enforcement).48 Furthermore, although United States citizenship is a mandated qualification for elected federal positions, the Constitution does not positively exclude dual nationals from such posts. So persons connected to foreign nations and holding foreign citizenship are not excluded from holding elected positions in the United States government. ${ }^{49}$ Again, this is some indication that Jay's position (which sought to exclude foreigners from service in the federal government) was not adhered to and that his letter did not supply any model for what became the Natural Born Citizen Clause.

Jay's position was not adopted with regard to the presidency and the commander-in-chief of the armed forces-at least, not in toto. The President of the United States is the commander-in-chief of United States armed forces. And in the normal course of events, presidents are elected, and subject to the Constitution's Natural Born Citizen Clause

\footnotetext{
${ }^{48}$ See Letter from John Jay, Secretary of Foreign Affairs, to George Washington, President of the Constitutional Convention (25 July 1787), supra note 45, at n.3. Jay struck out the following language in his letter: "that nonebut naturalborn citizens shall be admittod into our Legislatures or our national civil Gov[ornment]t shall be administered only by naral born citizons". Ibid. Arguably, Jay distinguished the legislature from the administration of the "national civil government." Ibid. ${ }^{49}$ Australia's constitution bans its own citizens from holding seats in the national parliament if they also hold foreign citizenship. See Australia Constitution (1900), Chapter 1, Part IV, Section 44; Sykes v Cleary [1992] 176 Commonwealth Law Reports 77 (High Court of Australia) (adjudicating a Section 44 dispute). The modern Australian position is much closer to the policy John Jay put forward than what was adopted by the Federal Convention.
} 


\section{DRAFT: Not for distribution DRAFT: Not for quoting}

\section{2(2) STUDY ON THE AMERICAN CONSTITUTION (forth. circa Sept. 2021)(peer reviewed) (South Korea)}

qualifications. But not all "presidents" are elected. "Acting presidents" are not elected; they succeed to the presidency under the authority of the Constitution's Presidential Succession Clause ${ }^{50}$ and the Presidential Succession Act of $1947 .{ }^{51}$ The prevailing view is that, as a constitutional matter, acting presidents are not subject to the constitutionally-imposed qualifications applicable to elected presidents. ${ }^{52}$ It follows that contrary to what Jay proposed in his 1787 letter, an acting president/commander-inchief of the armed forces need not be a natural born citizen. ${ }^{53}$ Again, this is some indication that Jay's position was not adhered to and that his letter did not supply any model for what became the Natural Born Citizen Clause. Nor is this a picayune critique about a subject absent real world consequences. ${ }^{54}$ Jay, in his letter, sought to restrict the position of commander-in-chief exclusively to natural born citizens. Furthermore, not only did Jay's letter address regularly appointed commanders-inchief, it also expressly addressed temporary commanders-in-chief: i.e., anyone who the powers of commander-in-chief might "devolve on." Jay sought to limit such temporary commanders to natural born citizens. The Federal Convention did not enact Jay's suggested policy.

\footnotetext{
50 See United States Constitution, Article1, Section 2, Clause 2.

${ }^{51}$ See Presidential Succession Act of 1947, 3 United States Code 119.

${ }^{52}$ See Mark Tushnet, Resolving the Paradox ofDemocratic Constitutionalism?(2000)

3 GREen BAG 2D 225, 226 n.1 (reviewing FranK I. Michelman, BrenNAN AND DEMOCRACY (Princeton, New Jersey: Princeton University Press, 1999)). Congress, acting by statute, has chosen to impose the Constitution's qualifications applicable to elected president on acting presidents who succeed by operation of the Presidential Succession Act of 1947. See 3 United States Code $§ 19(\mathrm{e})$ ("[T]his section shall apply only to such officers as are eligible to the office of President under the Constitution."); see also infra note 84 and accompanying text.

53 See James C. Ho, Unnatural Born Citizens and Acting Presidents (2000) 17 CONSTITUTIONAL COMMENTARY 575, 582-83 " That individual serves not as 'President,' but as 'Acting President'-a position for which the Constitution imposes no citizenship related eligibility requirements whatsoever ....”.). Judge Ho now sits on the United States Court of Appeals for the Fifth Circuit.

${ }^{54}$ For example, John Shalikashvili, a former Chairman of the Joint Chiefs of Staff of the U.S. military, is a naturalized United States citizen. See John Malchase David Shalikashvili, JoINT CHIEFs OF STAFF, <https://tinyurl.com/2vemf9nk>.
} 


\section{DRAFT: Not for distribution DRAFT: Not for quoting}

\section{2(2) STUDY ON THE AMERICAN CONSTITUTION (forth. circa Sept. 2021)(peer reviewed) (South Korea)}

Finally, on 26 July 1787, George Mason proposed adding property and citizenship qualifications for persons serving in each of the three branches of the federal government. ${ }^{55}$ Nothing ever became of Mason's proposed property qualifications, and Mason's proposal (like Hamilton's Plan) only spoke to citizenship as a qualification, absent any mention of a "natural born citizen" limitation.

As one commentator concluded: "no explanation of the origin or purpose of the [Natural Born Citizen Clause] appears anywhere in the recorded deliberations of the Convention." 56

3. The Ratification Period. The ratification period produced little discussion of qualifications for federal officeholders and the Natural Born Citizen Clause. Frequently, state conventions and discussions in the press glossed over the clause, with little or no substantive discussion. For example, at the Rhode Island state convention, which met in 1790 , the entirety of the discussion was "Second Article/1st Section/read-no objections." ${ }^{57}$ One anonymous commentator, American Citizen, wrote: “Our President must be matured by the experience of years, and being born among us, his character at thirty-five must be fully understood." ${ }^{58}$ American Citizen's position is somewhat undertheorized. "Being born" among a population will only produce some weak tendency, at best, towards establishing a public reputation for character. After all, a person born amongst the population can be sent abroad or live in isolation within. Still,

\footnotetext{
${ }^{55}$ See 1 Elliot's DeBATES, supra note 41, at 219, 219-20.

${ }^{56}$ Gordon, supra note 31, at 4; see also Post, supra note 19, at 192 (noting that the Natural Born Citizen Clause is "remarkably innocent of both legislative history and judicial gloss").

57 Theodore Foster, Minutes of the Convention Held at SOUth Kingston, RHODE IsLAND, IN MARCH, 1790, at 56 (Providence, Rhode Island: n.p., 1929). Foster's Minutes are state ratification materials. Albeit Rhode Island held these debates both after the United States Constitution was ratified in 1787, and after the Constitution putinto effect in 1788 (when the first federal electionswere held) and in 1789 (when the first Congress met).

${ }^{58}$ American Citizen I, IndEPENDENT GAZETTEer (26 September 1787). American Citizen's authorship is frequently ascribed to Tench Coxe.
} 


\section{DRAFT: Not for distribution DRAFT: Not for quoting}

\section{2(2) STUDY ON THE AMERICAN CONSTITUTION (forth. circa Sept. 2021)(peer reviewed) (South Korea)}

it is at least arguable that an immigrant coming to the United States at a very young age, and then naturalized, would be similarly placed to the native in this respect.

Federal Farmer and Alexander Hamilton, writing as Publius in Federalist No. 68, had an underdeveloped exchange on the issue. Federal Farmer wrote: "The election of this officer [the Vice President], as well as of the president of the United States seems to be properly secured ...." ${ }^{59}$ Citing Federal Farmer, Hamilton wrote:

THE mode of appointment of the Chief Magistrate of the United States is almost the only part of the system, of any consequence, which has escaped without severe censure, or which has received the slightest mark of approbation from its opponents. The most plausible of these, who has appeared in print, has even deigned to admit that the election of the Presidentis pretty well guarded. ${ }^{60}$

Hamilton continued:

Nothing was more to be desired, than that every practicable obstacle should be opposed to cabal, intrigue and corruption. These most deadly adversaries of republican government might naturally have been expected to make their approaches from more than one quarter, but chiefly from the desire in foreign powers to gain an improper ascendant in our councils. How could they better gratify this, than by raising a creature of their own to the chief magistracy of the union? ${ }^{61}$

At first blush, one might think that Hamilton's abstract language was also about the Natural Born Citizen Clause and that the clause's purpose was to

59 The Federal Farmer: Letter III (10 October 1787), reprinted in OBSERVATIONS LEADING TO A FAIR EXAMINATION OF THE SYSTEM OF GOVERNMENT, PROPOSED BY THE LATE CONVENTION; AND TO SEVERAL ESSENTIAL AND NECESSARY ALTERATIONS IN IT, INA NUMBER OF LETTERS FROM THE FEDERAL FARMER TO THE REPUBLICAN 15, 18 (n.p.: Thomas Greenleaf, 1787), <https:/tinyurl.com/5htwkfh2>, $<$ https://tinyurl.com/4ezjnnht>. Federal Farmer expressed similar sentiments again in early 1788. Federal Farmer: Letter XIV (17 January 1788), FoundERs' CONSTITUTION, <https://tinyurl.com/r45ekwb8> ("Viewing the principles and checks established in the election of the president, and especially considering the several states may guard the appointment of the electors as they shall judge best, I confess there appears to be a judicious combination of principles and precautions."). Some ascribe FederalFarmer's authorshipto Richard Henry Lee.

${ }^{60}$ Federalist No. 68 (12 March 1788)(Alexander Hamilton).

${ }^{61}$ Ibid. 


\title{
DRAFT: Not for distribution DRAFT: Not for quoting
}

\section{2(2) STUDY ON THE AMERICAN CONSTITUTION (forth. circa Sept. 2021)(peer reviewed) (South Korea)}

obstruct foreign powers' interfering in the nation's "councils." But Hamilton's passage continues with:

\begin{abstract}
But the convention have guarded against all danger of this sort, with the most provident and judicious attention. They have not made the appointment of the President to depend on any preexisting bodies of men, who might be tampered with beforehand to prostitute their votes; but they have referred it in the firstinstance to an immediate act of the people of America, to be exerted in the choice of persons for the temporary and sole purpose of making the appointment. And they have excluded from eligibility to this trust, all those who from situation might be suspected of too great devotion to the President in office. No senator, representative, or other person holding a place of trust or profit under the United States, can be of the numbers of the electors. Thus without corrupting the body of the people, the immediate agents in the election will at least enter upon the task free from any sinister bias. Their transient existence, and their detached situation, already taken notice of, afford a satisfactory prospect of their continuing so, to the conclusion of it. The business of corruption, when it is to embrace so considerable a number of men, requires time as well as means. Nor would it be found easy suddenly to embark them, dispersed as they would be over thirteen States, in any combinations founded upon motives, which though they could not properly be denominated corrupt, mightyet be of a nature to mislead them from their duty. ${ }^{62}$
\end{abstract}

In other words, Hamilton's focus in Federalist No. 68 was not on qualifications, but on the election of the President via electors spread across the nation, thereby rendering foreign interference difficult. Certainly, the passage teaches that foreign interference was a concern at the time, but it does not establish that it was $a$, much less the, primary concern behind the Natural Born Citizen Clause. This passage from Federalist No. 68 would have been a peculiarly appropriate placeto discuss the Natural Born Citizen Clause if its purpose, in fact, related to foreign interference.

Just as the Natural Born Citizen Clause generated little meaningful discussion at the Federal Convention, it generated little meaningful discussion during ratification. It may be worth asking why this is so.

${ }^{62}$ Ibid. 


\section{DRAFT: Not for distribution \\ DRAFT: Not for quoting}

\section{2(2) STUDY ON THE AMERICAN CONSTITUTION (forth. circa Sept. 2021)(peer reviewed) (South Korea)}

\section{Post-Ratification Materials on the Natural Born Citizen Clause.}

Before turning to post-ratification materials, here it will be helpful to shift the conversation towards explaining a moral dilemma.

(A.) A Moral Dilemma. Imagine two industrialized nations, A and B, at war - not just war, but total war, akin to the world wars, producing harms against one another and against third parties. Both nations A and B have relatively recent histories of oppressing domestic ethnic and racial minorities and denying full equality based on ethnicity, race, sex, religion, etc. But by the time hostilities began, Nation A has largely overcome that history, and it has enshrined substantive equality principles into its legal system. The good offices of a third-party neutral nation, acting as an intermediary, have established that both sides now desire face-to-face negotiations towards an armistice, and then a peace treaty. There is a hitch. Nation B will not meet with Nation A if A's delegation includes officials from a particular minority group. You can imagine who those persons would be: just think of Nazis vis-à-vis Jews, and other groups the former viewed as less than human.

Now one response by Nation A to such a precondition is simply procedural. Each side chooses its own delegates, absent preconditions and redlines from the other side. That said, negotiated positions, even prior to the start of formal negotiations, are not entirely unknown. Near the end of World War II, the United States shifted its (and, in effect, the Allied Powers') position from Japan's unconditional surrender to the unconditional surrender of Japan's armedforces. ${ }^{63}$ There is some historical evidence that this was an effort by the United States, in response to communications from the Japanese authorities, to offer the latter some limited assurances in regard to the role of the emperor in a continuing

${ }^{63}$ See Michael D. Pearlman, Unconditional Surrender, Demobilization, and the Atomic Bomb 7 (Combat Studies Institute 1996), $<$ https://apps.dtic.mil/sti/pdfs/ADA473544.pdf>. 


\section{DRAFT: Not for distribution \\ DRAFT: Not for quoting}

\section{2(2) STUDY ON THE AMERICAN CONSTITUTION (forth. circa Sept. 2021)(peer reviewed) (South Korea)}

imperial Japanese political system. ${ }^{64}$ Without these assurances surrender negotiations would have been further delayed.

Procedural propriety aside, there are pragmatic and normative reasons for Nation A to accept and to reject Nation B's precondition. The reasons to reject Nation B's precondition are obvious. First, Nation A's failing to reject the precondition is a break with its own practice and, perhaps, with its own historical good faith settlement of its own difficult past in regard to its minorities. Second, agreeing to this redline might reify such compromises at home and abroad, including, for example, possible future dealings with Nation B. Nation A's taking a principled stand is an opportunity to make Nation B reflect on its own practices. Third, Nation A might lose the benefits that flow from using its own "best" or most "qualified" citizens in negotiating a peace settlement.

Are there reasons for Nation A to accept Nation B's proposal? As a pragmatic matter, if Nation B is losing the war, Nation B may be willing to set aside its own redlines. On the other hand, sometimes an unjust society might have a just casus belli, and sometimes an unjust society, even one absent a just casus belli, might fight its opponents to a standstill or even emerge victorious. Happy endings are not the result of every war. This hypothetical is not premised on the good guys' prevailing.

What reasons (if any) are there for Nation A to accept Nation B's precondition? One reason is obvious: to end the war. And to end the war, negotiations must start. Any delay in starting negotiations is likely to extend the war, with all its concomitant downsides. For example, Nation A's refusal may be likely to furnish Nation B with propaganda points at home and abroad. Second, as long as Nation B's bombs rain down on Nation A's territory, people, and armed forces, even those among the discriminated against group in Nation A might be willing to concede this

\footnotetext{
${ }^{64}$ See Michael Schaller, The American Occupation OF JAPAN 10, 17-18 (New York: Oxford University Press, 1985).
} 


\section{DRAFT: Not for distribution DRAFT: Not for quoting}

\section{2(2) STUDY ON THE AMERICAN CONSTITUTION (forth. circa Sept. 2021)(peer reviewed) (South Korea)}

enemy-imposed wrongful condition to end the prospect of their being bombed and, also, to protect all their fellow citizens, in the discriminated against group or not, including those in the theatre of active war, from the prospect of an extended war.

But there is more. Nation B has prisoner of war camps (or worse). Among the prisoners from Nation A are citizens from all its groupsincluding the discriminated against group. How do Nation B's military authorities running those camps treat members of the discriminated against group? The more unjust and criminal Nation B is in administering those camps, the greater the obligation on Nation A's authorities to recover its own people in a timely way - while the prisoners remain alive. ${ }^{65}$ Would Jewish citizens of the World War II Allies have pressed their home governments for equal participation among the roles for negotiating an end to hostilities in Europe if their absence put the Allies in control of the death camps more quickly? Finally, some have even argued that a nation's statesmen, here Nation A's leadership, in fighting a war against a non-ideal

\footnotetext{
${ }^{65}$ See John Rawls, The Law of Peoples/The Idea of Public ReAson ReVisited 100102 \& n.26 (Cambridge, Massachusetts: Harvard University Press, 1999). Rawls argued that the "the bombings of Hiroshima and Nagasaki and the fire-bombing of Japanese cities were great wrongs." Ibid. He supported that position by noting that United States' armed forces had already defeated the Japanese military at Midway, in the Philippine Sea, Leyte, and in many Pacific islands. Interestingly, Rawls made no mention of the contribution of Australian, British, Chinese, Indian, and other Allied forces in those battles or, more generally, in the Asian-Pacific theatre of war. Nor did he discuss the countries and other territories which remained under military occupation until the time of the Japanese surrender. See also WILLIAM MANCHESTER, AMERICAN CAESAR: DOUGLAS MACARTHUR1880-1964, at 436 (New York: Little, Brown and Company, 1978) (noting that in 1945, Japan's generals "told each other [that] most of their conquests, including the Chinese heartland, were firmly in their hands." (emphasis added)). Finally, the millions of civilian internees and prisoners of war then under Japanese control did not enter Rawls's analysis.
} 


\section{DRAFT: Not for distribution DRAFT: Not for quoting}

\section{2(2) STUDY ON THE AMERICAN CONSTITUTION (forth. circa Sept. 2021)(peer reviewed) (South Korea)}

society, ${ }^{66}$ such as Nation $B$, have a substantial obligation to consider the harms that a continuing war would inflict on the enemy. ${ }^{67}$

Nation A's authorities, charged with making the decision to accept or to reject Nation B's precondition, will have to act in real time and with less than perfect information, particularly in regard to the consequences which will flow from the different decisions which they may decide to take. There is no easy answer to this question. Persons acting in good faith could arrive at divergent answers.

The larger point is that there is a substantial moral difficulty here. In assessing that difficulty, one is squarely confronted with the elastic quality of "merit" and "qualifications" in relation to holding government posts where there may be no widespread agreement what constitutes success. ${ }^{68}$ "Qualifications" include not only the would-be officeholder's manifesto or programme for future reform and negotiations, and the candidate's education and experience, but also include how “others," including one's opponents, react to the officeholder, and that may be true even where that reaction is based on prejudice and bigotry. ${ }^{69}$ To put it another way, the

\footnotetext{
${ }^{66}$ Ibid., at 89-113 (developing moral discourse around conflicts between ideal and non-ideal societies); John Rawls, The Law of Peoples (1993) 2O(1) CRITICAL INOUIRY 36.

${ }^{67}$ See generally ibid.

${ }^{68}$ See, e.g., John Randolph Prince, Forgetting the Lyrics and Changing the Tune: The Eleventh Amendment and Textual Infidelity (1999) 104DicKINSON LAW REView1, 94 ("It is entirely conceivable that the best person for the position of President might be some highly prominent public servant whose parents brought her here from another country as immigrants." (emphasis added)). What does the author mean by "best"?

69 The Supreme Court of the United States permits the government to use citizenship status as a factor in employment decisions for some public employment. See, e.g., Ambach v. Norwick, 441 U.S. 68 (Supreme Court of the United States 1979) (Powell, J.) (permitting state to exclude aliens from permanent certification as public school teachers); Foley v. Connelie, 435 U.S. 291 (Supreme Court of the United States 1978) (Burger, C.J.) (permitting state to exclude aliens from state police). It is noteworthy that the argument for affirmative action based on race or ethnicity is that qualifications are not entirely about education, experience, and civil service examination scores. Rather, the argument is that the
} 


\section{DRAFT: Not for distribution DRAFT: Not for quoting}

\section{2(2) STUDY ON THE AMERICAN CONSTITUTION (forth. circa Sept. 2021)(peer reviewed) (South Korea)}

difficulty is recognizing that there is an "other" whose existence, preferences, and demands we ought to consider, even in situations where the other's demands are unfair, and even in situations where one decides not to make concessions to the "other."

(B.) Modern Post-Ratification Materials. In a Congressional Research Service report, Jack Maskell wrote:

The apparent purposes of this citizenship clause were thus to assure the requisite fealty and allegiance to the nation from the person to be the chief executive of the United States, and to prevent wealthy foreign citizens, and particularly wealthy foreign royalty and their relatives, from coming to the United States, becoming naturalized citizens, and then scheming and buying their way into the Presidency or creating an American monarchy. ${ }^{70}$

Similarly, Professor Akhil Reed Amar wrote that the clause was motivated by fear that "a foreign earl or duke might cross the Atlantic with immense wealth and a vast retinue, and thenuse his European riches to buy friends on a scale that no homegrown citizen could match" which might "pervert Americandemocracy."71

Notice how there is no "other" in this discussion.

The danger of a European nobleman's establishing a monarchy in the United States is not that the American polity, in effect, would be conquered with a concomitant loss of hard-won independence, or that the United States would be merged into an extant European state-such as the United Kingdom or France. If a monarchy were launched in the United States, it is

system benefits when the police officer and the community s/he patrols are in the same group. Likewise, there may be systemic benefits where a teacher and student are in the same group. Undoubtedly, this is a contestable empirical claim. Greater or lesser effectiveness with regard to hiring decisions may be connected to the target group's experience with prejudice at the hands of other population groups or arising in connection with its own bigotry vis-à-vis outsiders. If, when, and how wider society should adapt to such a situation, with the concomitant risk of rewarding and reifying it, is a substantial element of the question athand.

${ }^{70}$ Jack Maskell, Congressional Research Service, R42097, Oualificationsfor the President and the "Natural Born" Citizenship Eligibility Requirement 8 (2016), $<$ https://www.everycrsreport.com/reports/R42097.html>.

${ }^{71}$ AMAR, supra note 47, at164-65. 


\section{DRAFT: Not for distribution \\ DRAFT: Not for quoting}

\section{2(2) STUDY ON THE AMERICAN CONSTITUTION (forth. circa Sept. 2021)(peer reviewed) (South Korea)}

not described as an extension of a foreign monarchy, but is instead described as something akin to an American one. Undesirable-yes, but essentially foreign? - no. According to these commentators, the motivating fear (i.e., the underlying policy concern) for the Natural Born Citizen Clause is that the candidate might lack the "requisite fealty and allegiance"-as if those connections were merely insufficiently developed or had not quite matured. The motivating fear expressed by these commentators is not that the candidate is totally disconnected from the United States, its land, its people, its linguistic heritage and literature, culture, and civilization, ${ }^{72}$ or, that the presidential candidate's loyalties lie entirely with some foreign polity or ruling family. Such possibilities are not plainly stated-they are, at most, hinted at. But such concerns are not directly voiced. If such concerns were brought to the readers' attention, they might undermine the rationales for the relatively generous constitutional provisions admitting foreign-born U.S. citizens to all other elected and appointed national positions in the government.

Professor Amar expresses some concern that normal political competition for otherwise competitive posts would be prevented or, better, crowded out by great wealth having European aristocratic sources. The concern here is expressed as essentially an intramural or distributional failure relating to political competition, and even where the corruption concern is characterized as a "perver[sion] [of] American democracy," it does not characterize the injury as a foreign power conquering the United States. The potential for failure by admitting the foreign born is not described in crisis-like or existential terms; rather, it is described in the policy-wonk's precautionary language associated with humdrum institutional design in connection with American aspirational good governance norms.

\footnotetext{
${ }^{72}$ See Kennedy, supra note 19, at 176 (referring to "country, polity, [and] a way of life").
} 


\title{
DRAFT: Not for distribution DRAFT: Not for quoting
}

\section{2(2) STUDY ON THE AMERICAN CONSTITUTION (forth. circa Sept. 2021)(peer reviewed) (South Korea)}

Turning to commentators who object to the Natural Born Citizen Clause, consider Professor Randall Kennedy (Harvard Law School) and

Professor Robert Post (Yale Law School). Professor Kennedy wrote:

\begin{abstract}
One concrete way of measuring the extent to which people affiliated with different social groups are full and equal members of this nation is to ask whether a person associated with that group could plausibly be elevated to the highest office in the land....

Formally barred from the Presidency . . . are people who may have invested their all, even risked their lives, on behalf of the nation.... This idolatry of mere place of birth seems . . . an instance of rank superstition. Place of birth indicates nothing about a person's willed attachment to a country, a polity, a way of life. It only describes an accident of fate over which an individual had no control. It is a truly 'immutable' aspect of one's biography, in today's world more so even than ethnicity or gender.

All citizens of the United States should have an equal legal right to vie for the nation's highest office, more precisely, any inequalities in that right should require a full defense.... But Article II imposes a totally unjustified inequality. There are many reasons why Henry Kissinger should not have become President, but his having been born in Germany is certainly not one of them. The natural-born citizen requirement embodies the presumption that some citizens of the United States are a bit more authentic, a bit more trustworthy, a bit more American than other citizens of the United States, namely those who are naturalized..$^{73}$
\end{abstract}

Kennedy's position is probably widely shared, ${ }^{74}$ but it comes without bona fides or meaningful analysis. He states without equivocation that the Natural Born Citizen Clause's restricting the presidency to natives is rooted in the view that native born citizens are "a bit more trustworthy." But he supplies no sources establishing that this particular view, or anything like it, supplied the motivation for the clause's inclusion in the Constitution (1787). Because the possibility of some other motivation for

\footnotetext{
${ }^{73}$ Kennedy, supra note19, at176.

${ }^{74}$ Compare, e.g., ibid. ("One concrete way of measuring the extent to which people affiliated with different social groups are full and equal members of this nation is to ask whether a person associated with that group could plausibly be elevated to the highest office in the land...."), with Ho, supra note 53, at576 ("One way to assess whether an individual is a full and equal member of a community is to ask whether the individual is eligible to serve in the highest office in thatcommunity.").
} 


\section{DRAFT: Not for distribution DRAFT: Not for quoting}

\section{2(2) STUDY ON THE AMERICAN CONSTITUTION (forth. circa Sept. 2021)(peer reviewed) (South Korea)}

the clause's inclusion is not even admitted, none is discussed. His conclusion is not merely that the clause is unjustified, but that it is "totally unjustified," which seems an unusually strong claim (particularly absent sources). His position that the test of societal fairness is the openness of the government's highest position to all comers would consign every inherited monarchy to obloquy. All things being equal, Post's position may be the better view-maybe monarchy, including constitutional monarchy, is a poor way to govern. But that view is not the only view or even the only reasonable view. It is just another contestable political position. Many constitutional monarchs can be removed and the monarchies themselves terminated by a statute passed in the ordinary course of parliamentary business using ordinary majority rule. As a result, such monarchies carry democratic bona fides, which is some justification for maintaining them in spite of the abstract reasoning of academics and other elites who oppose that form of government. ${ }^{75}$ Indeed, given the odd vagaries of the American electoral college and its imperviousness to democratic reform by simple majoritarian mechanisms, it might be argued that such monarchies carry better democratic bona fides than the American presidency.

Finally, Kennedy tells the reader: "Place of birth indicates nothing about a person's willed attachment to a country, a polity, a way of life.” As a pragmatic matter, Kennedy's claim here is somewhat of an oversimplification. The vast majority of American citizens born in the United States carry U.S. citizenship and only U.S. citizenship. By contrast, naturalized U.S. citizens in the vast majority of cases carry some foreign citizenship. When the latter become naturalized United States citizens,

\footnotetext{
${ }^{75}$ See generally EDMUND BURKE, REFLECTIONS ON THE REVOLUTION IN FRANCE, AND ON THE PROCEEDINGS IN CERTAIN SOCIETIES IN LONDON RELATIVE TO THAT EVENT: IN A LETTER INTENDED TO HAVE BEEN SENT TO A GENTLEMAN IN PARIS (London, England: J. Dodsley, 1790) (decrying abstract reasoning as a basis for constitutional settlement in favor of models relating to inheritance and long-standing practices and traditions).
} 


\section{DRAFT: Not for distribution \\ DRAFT: Not for quoting}

\section{2(2) STUDY ON THE AMERICAN CONSTITUTION (forth. circa Sept. 2021)(peer reviewed) (South Korea)}

their foreign citizenship is not recognized (for most purposes) under U.S. law. Nevertheless, the United States does not compel its naturalized citizens to give up their foreign citizenship. And, not surprisingly, very few naturalized U.S. citizens make active efforts to do so. In short, as a practical matter, "place of birth" does tell us something about one's "willed attachment to a country." Some people (i.e., the natives) will have a "willed attachment" to one country, while others (i.e., naturalized citizens, but also some natives) will have a "willed attachment" to two or more countries. Similarly, while one might admit that some natural born citizens will spend their formative years abroad, many (if not most) of those will do so under the tutelage and direction of at least one American parent, and frequently they will attend American-affiliated schools or schools offering American curricula. By contrast, when foreigners who grow up abroad-i.e., in their birth countries - become naturalized U.S. citizens, they will reach their new political identity having come with connections to "a [foreign] polity, [and] a [foreign] way of life" in a fashion a large majority of native born citizens will not have done. These different experiences and associated skill sets do not make them less than "trustworthy," and, in fact, they may make them particularly useful, including in times of war and other crises, to their fellow American citizens - native and foreign born. But it does, in a substantial majority of cases, situate them differently from most native born citizens. One might suggest that the latter are more likely to identify with a single country: the United States. Admittedly, that's a contestable empirical proposition, but it is not falsified merely by Professor Kennedy's strong language.

In a second article, offering even stronger objections to the Natural Born Citizen Clause, titled What is the Constitution's Worst Provision, Professor Post wrote:

[The Natural Born Citizen Clause] is remarkably innocent of both legislative history and judicial gloss. . . . [T]he Clause is highly 


\section{DRAFT: Not for distribution DRAFT: Not for quoting}

\section{2(2) STUDY ON THE AMERICAN CONSTITUTION (forth. circa Sept. 2021)(peer reviewed) (South Korea)}

objectionable because it unmistakably and clearly prohibits naturalized citizens from becoming President.

Without doubt [in 1833] Joseph Story correctly identified the purpose of this prohibition as cutting "off all chances for ambitious foreigners, who might otherwise be intriguing for the office." We might therefore understand the Clause as resting on three propositions: It distinguishes citizens from foreigners; it reserves the Office of the Presidency for the former; and it classifies naturalized citizens with the latter. It is the third and last proposition that I find so disturbing.

Our constitutional order does not ordinarily distribute the prerogatives of citizenship on the basis of where or how one is born. Allegiance is the sign of membership. Because allegiance is a matter of voluntary commitment rather than birth, it should not systematically differ as between naturalized and natural born citizens.

[A]t the very heart of the constitutional order, in the Office of the President, the Constitution abandons its brave experiment of forging a new society based upon principles of voluntary commitment; it instead gropes for security among ties of blood and contingencies of birth. . . . It is a vestigal [sic] excrescence on the face of our Constitution. ${ }^{76}$

Post's position, like Kennedy's, is judgmental, rather than dispassionate.

Phrases like "vestigial excrescence" are not common to U.S. law journals.

He starts by telling the reader that there is little information on the clause.

He then turns to Joseph Story's Commentaries on the Constitution, a treatise from 1833-more than forty years after 1787. Here, Post assures the reader that Story's position "without doubt . . . correctly identified the purpose of the clause." How Post came to this determination is unexplained. His complaint against the clause is that it abandoned the "brave experiment of forging a new society based upon principles of voluntary commitment" and that "allegiance is a matter of voluntary commitment rather than birth." Is that correct? If you are born in the United States, you owe it allegiance-that's fixed in stone by the Fourteenth Amendment. That was true for white people before the Fourteenth Amendment ${ }^{77}$ was ratified, and

\footnotetext{
${ }^{76}$ Post, supra note 19, at192 (footnotes omitted).

${ }^{77}$ United States Constitution, Amendment14(1868).
} 


\section{DRAFT: Not for distribution DRAFT: Not for quoting}

\section{2(2) STUDY ON THE AMERICAN CONSTITUTION (forth. circa Sept. 2021)(peer reviewed) (South Korea)}

it was true for people of every race afterwards. ${ }^{78}$ Voluntariness has nothing to do with it. ${ }^{79}$ Noncitizens can be naturalized-but United States naturalization authorities will naturalize adults and children. And children do not meaningfully volunteer to become citizens. Post's belief that voluntariness is a central organizing principle behind citizenship and allegiance is both mysterious and unexplained.

It is possible that Professor Post's "voluntariness" language is really libertarian code acting as a cover to normatively prescribe an individualized assessment of loyalty, ${ }^{80}$ as opposed to a coarse group standard, for qualifications for public office. That might be the right policy, but it is equally a reason to open up all positions to actual aliens - those who are not now and who do not intend to become naturalized citizens. Citizenship-status is just another group qualification or standard acting as a proxy for loyalty. If Post's position is that the naturalization process and its tests separate loyal wheat from disloyal chaff, then that too is a contestable empirical claim which calls for evidence, as opposed to his mere strong language of disgust relating to "vestigial excrescence[s]."

James C. Ho, then a practitioner, and now a federal appellate judge, wrote that he and other naturalized citizens face a "a certain measure of exclusion" in consequence of the Natural Born Citizen Clause. ${ }^{81}$ Still his

\footnotetext{
${ }^{78}$ Of course, there are exceptions, including: "the child of an ambassador or other diplomatic agent of a foreign state, or of an alien enemy in hostile occupation of the place where the child was born." United States v. Wong Kim Ark, 169 U.S. 649, 658 (Supreme Court of the United States 1898) (Gray, J.).

79 See RAWLE, supra note 1, at 80-81 (expressly rejecting the concept that citizenship is a voluntary relationship, and asserting, instead, that under United States law citizenship follows from place of birth, i.e., birth in the United States). ${ }^{80}$ See Oyama v. California, 332 U.S. 633, 666 (Supreme Court of the United States 1948) (Murphy, J., concurring) ("Loyalty and the desire to work for the welfare of the state, in short, are individual rather than group characteristics. An . . alien may or may not be loyal; he may or may not wish to work for the success and welfare of the state or nation. But the same can be said of an eligible alien or a natural born citizen.").

${ }^{81} \mathrm{Ho}$, supra note 53, at 575 and 576.
} 


\section{DRAFT: Not for distribution DRAFT: Not for quoting}

\section{2(2) STUDY ON THE AMERICAN CONSTITUTION (forth. circa Sept. 2021)(peer reviewed) (South Korea)}

paper has no substantial discussion ${ }^{82}$ what purpose the clause serves. Indeed, he took no position whether the clause is useful; instead, he wrote: "Perhaps, this business of distinguishing between natural born citizens and merely naturalized (unnatural?) citizens for purposes of [p]residential eligibility makes sense; perhaps not." 83 He is strangely agnostic, notwithstanding his personal exclusion from eligibility to the presidency. Instead, he notes that Congress has imposed by statute the United States Constitution's qualifications for elected presidents on temporary or acting presidents, ${ }^{84}$ and he weakly recommends that those statutory restrictions be relaxed. He offers two reasons. First, such a statutory reform would allow "members of a previously excluded class of individuals some opportunity to prove that loyalty to the United States, the Constitution, and our founding principles of freedom and democracy is not the exclusive province of the native-born." ${ }^{55}$ Second, such a reform "would bring[] millions of American citizens just one step closer to full representation by their President." 86 It is puzzling. The reasons Ho puts forward for relaxing those statutory restrictions, and for allowing naturalized citizens to serve as acting presidents would seem to apply equally to regularly elected presidents. But his paper makes no recommendation in regard to amending the Constitution in a similar fashion-even as an aspirational goal. If equal

\footnotetext{
82 See ibid., at 585 (closing publication with the argument that permitting naturalized citizens to serve as acting President "is a step that would extend to millions of current and future [American?] mothers and fathers the distinctively American dream that their children might someday grow up to be (acting) President."). But cf. Abraham Lincoln, Speech to the 166th Ohio Regiment, Washington, D.C., August 22, 1864, House Divided: THe Civil WAR REsEarch ENGINE AT DICKINSON COLLEGE/150TH ANNIVERSARY EDITION, <http://hd.housedivided.dickinson.edu/node/40421> ("I happen temporarily to occupy this big White House. I am a living witness that any one of your children may look to come here as my father's child has.").

${ }^{83}$ Ibid., at 576 (footnotes omitted).

${ }^{84}$ Ibid., at 583; see supra note 52 and accompanyingtext.

${ }^{85}$ Ibid., at 585.

${ }^{86}$ Ibid.
} 


\section{DRAFT: Not for distribution DRAFT: Not for quoting}

\section{2(2) STUDY ON THE AMERICAN CONSTITUTION (forth. circa Sept. 2021)(peer reviewed) (South Korea)}

participation rights are the test of fair governance, and if loyalty-related concerns are of no concern, then distinguishing the qualifications for elected and temporary presidents becomes difficult to justify.

(C.) Early Post-Ratification Materials. As opposed to the modern post-ratification materials, discussed above, the early postratification materials did not mince words. They are not oblique. They express a very definite point of view in regard to the purpose of the Natural Born Citizen Clause: the clause exists to obviate the risk of war.

In 1826, Chancellor Kent explained that the purpose of the Natural Born Citizen Clause was to preclude "ambitious foreigners [from engaging in] intrigue for the office, and the qualification of birth cuts off all those inducements from abroad to corruption, negotiation, and war."87

Writing in 1833, James Bayard Jr. stated:

Were foreigners eligible to the office [of the presidency], it would be an object of ambition, or of policy, with foreign nations, to place a dependent in the situation; and scenes of corruption and bloodshed, which disgraced the annals of Poland, might have been acted over again in this country. The necessity of citizenship by birth, precludes this, by rendering it impossible for any foreigner ever to become a candidate." 88

\section{The Natural Born Citizen Clause and Three Hypotheticals Relating to}

War and Peace. Consider the following hypotheticals. Imagine a longenduing rivalry between two world-wide empires: Empire A and Empire B. Each has its capital in Europe. The two empires go to war against one another from time totime. There is no long-term optimism for world peace. The consequences of such wars are devastating. The United States tries to stay neutral, butU.S. merchant ships are attacked. The United States offers to mediate.

\footnotetext{
${ }^{87} 1$ JAMES KENT, COMMENTARIES ON AMERICAN LAW 255 (New York: O. Halsted,1826), $<$ https://tinyurl.com/8bf5hw2m $>$.

88 JAMES BAYARD, A BRIEF EXPOSITION OF THE CONSTITUTION OF THE UNITED STATES 96 (Philadelphia, Pennsylvania: Hogan \& Thomson, 1833), $<$ https://tinyurl.com/5yh8db6y>.
} 


\section{DRAFT: Not for distribution DRAFT: Not for quoting}

\section{2(2) STUDY ON THE AMERICAN CONSTITUTION (forth. circa Sept. 2021)(peer reviewed) (South Korea)}

The President will choose one of two senior State Department candidates to act as chief mediator. Both candidates are U.S. citizens; both are equally loyal to the United States; and both are equally good choices in terms of traditional "merits" or "qualifications."

One candidate was born in the United States, and he is able to trace his American heritage back six generations through both his father and mother. His ancestors served in the active U.S. military during the American Civil War and both world wars.

By contrast, the other candidate was born in Empire A, grew up in Empire A until the age of 16, was educated there, which is where his extended family remains, and then, at the age of 16, immigrated to the United States with his immediate family after they and he had been bombed by Empire B's military (in a prior conflict). The second candidate subsequently became a naturalized U.S. citizen, albeit, he has never formally givenup his Empire-A citizenship. Arguably, he is a dual national. Culturally, he retains some "connections" with Empire A. ${ }^{89}$

If you were the President, which candidate would you choose?

Which candidate is more likely to mediate the dispute successfully?

If you think it reasonably clear that the second candidate would be the lesser choice-despite that candidate's loyalty, allegiance, and trustworthiness, then you are admitting that reasonable judgments relating to "merits" and "qualifications" are not entirely co-extensive with

\footnotetext{
89 Does the extent of the second candidate's continuing post-naturalization cultural contacts with Empire A affect one's analysis? E.g., The candidate attends a church in communion with Empire A's state church. He speaks Empire A's dominant non-English European language. He has frequently vacationed in Empire A since becoming an adult. He is a member of its bar. He has taught in its state universities, where his own children have been educated. His family's burial plot is there, and he intends to be buried there himself. His spouse is a Nation-A citizen, and the couple was married there, where her immediate family abides. It goes without saying that not one of these connections is evidence of any "disloyalty" to the United States. But should these connections, nevertheless, influence our choice between rival candidates?
} 


\section{DRAFT: Not for distribution \\ DRAFT: Not for quoting}

\section{2(2) STUDY ON THE AMERICAN CONSTITUTION (forth. circa Sept. 2021)(peer reviewed) (South Korea)}

traditional prudential judgments involving the candidate's policy approach, education, skills, and experience. The candidate's actual merits do not relate in toto either to the individual candidate's abstract qualifications or to intramural (American-focused) distributional consequences among competing (American) pools of candidates in connection with their group status, ethnicity, national origin, etc. Instead, the better choice is connected with the function of the position and the candidate's likelihood of success in that position. The latter might turn on how foreigners react to the American candidate. How the foreigners react to the American candidate for chief mediator might be rooted in their own reasonable prudential judgments, or it might arise in consequence of bigotry, prejudice, and other irrational preconceptions. In any event, the foreigners' reaction(s) might define the possibility for a successful mediation, where the stakes are large. The President's choosing a chief mediator based upon what he believes will be Empire B's reaction might work an unfairness vis-à-vis the individual candidate. In some instances, that unfairness might be so great that the United States might (and should) walk away from the process or simply tell Empire B that the United States chooses its functionaries as it sees fit. But the President might not take that approach. The President might tell the second candidate.

You hold and have held high positions of trust in the State, and will hold others in the future. The success of this diplomatic mission will raise all boats-the prestige of the United States and my administration, the condition of the people in the warring states and neutrals, and the safety of all our people living abroad, along with the commercial interests of our people engaged in foreign trade. It might be unfair to you individually, but the stakes are too large for me to allow that admitted, individualized unfairness to determine mychoice.

Contra Professor Kennedy and Professor Post, is not the president's approach in this hypothetical a reasonably fair or good one-at least in some circumstances? 


\section{DRAFT: Not for distribution \\ DRAFT: Not for quoting}

\section{2(2) STUDY ON THE AMERICAN CONSTITUTION (forth. circa Sept. 2021)(peer reviewed) (South Korea)}

Now take a step back. Assume there is no Natural Born Citizen Clause. Here, the hypothetical is not that the President is choosing between two candidates for chief mediator. Instead, you, the voter, are choosing between two otherwise similarly placed presidential candidates - one foreign born (but now a naturalized citizen) and one native born. It is understood that the President will personally attend and chair the peace conference at the head of the American diplomatic delegation. Would it be entirely wrong for a voter to vote for the native-born presidential candidate, and against the foreign born one based on their different life stories? In such circumstances, the former candidate benefits from the fortuity of birth, blood, time, and place. If your answer is yes - that a voter could reasonably cast his vote on such a basis, then one might argue that the Natural Born Citizen Clause is but one short step removed from that choice. The Natural Born Citizen Clause constitutionalizes the choice of the hypothetical president (appointing the chief mediator) and the hypothetical voter (electing a President), discussed above.

Now consider a second hypothetical. Assume, again, there is no Natural Born Citizen Clause. Empire A and Empire Bare at war. The United States is holding a presidential election. The two candidates for President of the United States have similar party manifestos, etc. But their vitas are those of the two hypothetical chief mediators described above. If you were a citizen of Empire B and an advisor to its government, how (if at all)would you advise your government to react to this situation? Would you do nothing at all? Would your citizens (and posterity) think such conduct responsible? What would your citizens think if you chose not to respond or interfere in the U.S. election? Is it obvious what counts as lawful speech or unlawful interference-under the standards of public international law and domestic U.S. law? Would not your advice, given during the exigencies of war time, and with less than perfect information, depend on many contingencies and imponderables relating to military developments and 


\section{DRAFT: Not for distribution \\ DRAFT: Not for quoting}

\section{2(2) STUDY ON THE AMERICAN CONSTITUTION (forth. circa Sept. 2021)(peer reviewed) (South Korea)}

the likelihood of your successfully affecting the outcome of the U.S. election?

Now consider a third hypothetical. You are now a delegate to your country's constitutional convention. Your independent country is relatively new, not particularly wealthy, and not especially powerful. But you know there will be wars, and the great powers have an interest, if not in moving your nation onto "their" side, at least in keeping your nation from allying with the "other" side. Naturally, you fear such entanglements, and you fear interference by these foreign nations in your decision-making. You fear such interference because if it is successful, it means you will not be the master in your own home. You fear it because the actions of one foreign power might lead to counter-efforts by their foreign opponents. And you fear it because the result may not just beloss of control in elections, but domestic disputes about fair-play during contested elections which could lead to civil strife and, perhaps, to civil war amongst rival domestic personalities and factions. You have no clear idea how far the great powers will go to keep your country from upsetting their plans.

In these circumstances, one way to think about the Natural Born Citizen Clause is that it was an effort by the Constitution's Framers to pacify the United States' relationship with foreign powers. It was a unilateral effort to indicate that the new nation wanted peace with the world's great powers -its cost was that it bound the hands of the public when choosing some of their future leaders. ${ }^{90}$ It was an attempt to take the circumstances of all the hypotheticals posed above off the policy-making table by assuring foreign powers that the new and relatively weak American Republic intended to stay out of Europe's wars. Thus, it is really

\footnotetext{
90 See, e.g., Sanford Levinson and Jack M. Balkin, Constitutional Crises (2009) 157 UNIVERSITY OF PENNSYLVANIA LAW REVIEW 707,729 n.88 ("The Natural Born Citizen Clause of Article II keeps talented persons from serving as President."). Levinson and Balkin's critique of the Natural Born Citizen Clause is correct, but their critique equally applies to all other qualifications.
} 


\section{DRAFT: Not for distribution DRAFT: Not for quoting}

\section{2(2) STUDY ON THE AMERICAN CONSTITUTION (forth. circa Sept. 2021)(peer reviewed) (South Korea)}

no surprise that John Jay, who recommended using "natural born citizen" language, was the nation's Secretary of Foreign Affairs, as opposed to a cabinet member having purely domestic responsibilities. The Natural Born Citizen Clause was never about us (Americans) - native born or foreign born; it was always about them (foreign powers).

\section{Conclusion.}

The efforts of the modern commentators to explain the Natural Born Citizen Clause as one rooted in bigotry ${ }^{91}$ and prejudice directed at naturalized citizens is the product of an intellectual milieu of large, powerful countries, where there is no memory of bombs falling on the nation's core territory or any existential fear of conquest by foreign powers. The concern of these authors is merely the fair, intramural distribution of society's benefits and opportunities, between citizens and immigrants, and between native-born and foreign-born citizens. The "other," to the extent he exists at all, is just a person who has not yet become or who has not yet been allowed to become an American.

Modern theories of separation of powers and constitutional design have little or nothing to do with the Framers' and Founders' world of revolutions and imperial wars-where oceans and frontiers pose dangers - as you yourself pose dangers to others - where others may burn down your capital as you may burn down theirs. The Natural Born Citizen Clause was the limited policy response of a People who believed that beyond one's national frontier was a dangerous world. That the clause's

\footnotetext{
${ }^{91}$ See, e.g., Laurence H. Tribe, "NaturalBorn Citizen" as Illuminated by the Cruz Candidacy (2017)161(2) PROCEEDINGS OFTHE AMERICANPHILOSOPHICAL SOCIETY 111, 125 (characterizing the original public meaning of Article II's presidential eligibility rules as "offensively discriminatory, nativist, and xenophobic"); Laurence H. Tribe, Reflections on the "Natural Borm Citizen" Clause as Illuminated by the Cruz Candidacy, HARVARD CIVIL RIgHTS-CIVIL LIBERTIES LAW REVIEW BLOG (15 September 2016), <https://tinyurl.com/h5mevuzc> (same). But see ibid. (characterizing the United States as "an entire nation of immigrants," absent excepting the indigenous inhabitants).
} 
DRAFT: Not for distribution

DRAFT: Not for quoting

32(2) STUDY ON THE AMERICAN CONSTITUTION (forth. circa Sept. 2021)(peer reviewed) (South Korea)

purpose is no longer widely understood indicates that much has changed since 1787. 